\title{
Pilot-scale validation of Enzymatic Reactive Distillation for butyl butyrate production
}

DOI:

10.1016/j.cej.2016.11.127

\section{Document Version}

Accepted author manuscript

Link to publication record in Manchester Research Explorer

\section{Citation for published version (APA):}

Wierschem, M., Schlimper, S., Heils, R., Smirnova, I., Kiss, A. A., Skiborowski, M., \& Lutze, P. (2017). Pilot-scale validation of Enzymatic Reactive Distillation for butyl butyrate production. Chemical Engineering Journal, 312, 106117. https://doi.org/10.1016/j.cej.2016.11.127

\section{Published in:}

Chemical Engineering Journal

\section{Citing this paper}

Please note that where the full-text provided on Manchester Research Explorer is the Author Accepted Manuscript or Proof version this may differ from the final Published version. If citing, it is advised that you check and use the publisher's definitive version.

\section{General rights}

Copyright and moral rights for the publications made accessible in the Research Explorer are retained by the authors and/or other copyright owners and it is a condition of accessing publications that users recognise and abide by the legal requirements associated with these rights.

\section{Takedown policy}

If you believe that this document breaches copyright please refer to the University of Manchester's Takedown Procedures [http://man.ac.uk/04Y6Bo] or contact uml.scholarlycommunications@manchester.ac.uk providing relevant details, so we can investigate your claim.

\section{OPEN ACCESS}




\title{
Pilot-Scale Validation of Enzymatic Reactive Distillation for Butyl Butyrate Production
}

\author{
Matthias Wierschem $^{1, *}$, Stefan Schlimper ${ }^{1}$, Rene Heils ${ }^{2}$, Irina Smirnova ${ }^{2}$, Anton A. Kiss ${ }^{3,4}$, \\ Mirko Skiborowski ${ }^{1}$, Philip Lutze ${ }^{1}$ \\ ${ }^{1}$ Laboratory of Fluid Separations, TU Dortmund University, Emil-Figge-Str. 70, 44227 \\ Dortmund, Germany \\ ${ }^{2}$ Institute of Thermal Separation Processes, TU Hamburg, Eißendorfer Str. 38, 21073 \\ Hamburg, Germany \\ ${ }^{3}$ AkzoNobel Research, Development \& Innovation, Process Technology SRG, Zutphenseweg \\ 10, 7418 AJ Deventer, The Netherlands. \\ ${ }^{4}$ Sustainable Process Technology Group, Faculty of Science and Technology, University of \\ Twente, PO Box 217, 7500 AE Enschede, The Netherlands \\ *Corresponding author: matthias.wierschem@bci.tu-dortmund.de
}

Keywords: Biocatalysis, Hydrodynamic, Lipase, Modeling, Process intensification, Reactive distillation

\section{Highlights}

- Butyl butyrate synthesis by Enzymatic Reactive Distillation is possible

- Established rate-based model to describe Enzymatic Reactive Distillation

- First time validation for an Enzymatic Reactive Distillation process model

\begin{abstract}
For enzyme-catalyzed reactions, batch processes using stirred tank reactors are the state-ofthe-art production mode. The yield of the process may be limited by reaction equilibrium, product inhibition of the enzyme, low concentrations and possibly low reaction rates, while the recovery of the product may be limited due to thermodynamic constraints such as azeotropes. Using enzymes in an integrated reactive distillation process can overcome these limitations and provides a cost advantage over classic batch reactor processes.

The aim of this paper is i) to report the successful pilot-scale experimental validation of an Enzymatic Reactive Distillation (ERD) process for the synthesis of butyl butyrate and ii) to
\end{abstract}


establish a rate-based model for conceptual process design which can be quickly adapted to other systems.

The main novelty is the application of a continuous RD column with enzymes as a heterogeneous catalyst provided in two different types of catalytic packing: loosely filled immobilized enzyme beads in standard packings with catalyst pockets and gauze packings with catalytic coating.

Experimental pilot-scale experiments show the feasibility of ERD and allow the comparison of the different packing types based on catalytic performance as well as stability. Furthermore, these experiments are used to validate a predictive rate-based model to describe ERD which can be used to check the sensitivity of process and design parameters as well as to provide a quick adaption to other systems for quick evaluation. 


\section{Introduction}

Biocatalysis underpins some of the oldest chemical transformations known to humankind, and it has become a key component in the toolbox of chemists and chemical engineers, allowing new green chemistry and highly productive processes to be developed [1]. Enzyme-catalyzed processes are used in many industrial processes, as for example the synthesis of enantiomerically pure chemicals which are important as intermediates in the pharma- and agro-industry [2]. The pharmaceutical and fine chemicals industry is demanding for economically more attractive processes [2]. Still, the most commonly used production mode for enzyme-catalyzed reactions is based on batch processes using stirred tank reactors [3]. These processes lack in productivity and product purity [1]. A key problem is the increasing concentration of the reaction products that can cause inhibitory or toxic effects or promote unfavorable equilibria. In such cases, in-situ product removal is used to remove the product as soon as it is formed in order to overcome the constraints and increase the productivity and space-time-yield of the bioprocess [4]. In fine chemicals or pharmaceutical production, continuous production can significantly enable increased throughput, process safety, greener production [5], process automatization and control, easier modeling, smaller hold-up of solvents, improved heat transfer and a cost reduction in operation and installation [6].

Integrated and/or intensified processes are important tools for the successful and cost-efficient realization - one technique of process intensification is reactive distillation (RD) which realizes the integration of reaction and product removal by distillation in one apparatus, which opens up for potential higher conversion, selectivity, efficiency and capacity [7]. Using enzymes in combination with a RD process instead of a classic batch process can overcome chemical and phase equilibrium, and can deliver a cost-effective alternative to classic batch processes [8]. Heils et al. (2015) investigated an enantio-selective biocatalytic reaction carried out in a fully integrated batch RD setup [9].

However, as RD using chemical catalysts either homogeneous or heterogeneous has been presented many times before [10,11], while to the best of our knowledge there are no experimental reports on continuous Enzymatic Reactive Distillation (ERD) processes. Furthermore, different models such as equilibrium or rate-based approaches for RD using chemical catalysts have been developed and successfully used to evaluate feasibility, cost competitiveness or process optimization [12]. However, such models do not yet exist for ERD processes. Therefore, this study aims to fill this gap i) by being the first to report the pilotscale experimental validation of an ERD process based on the synthesis of butyl butyrate and ii) by establishing and validating a rate-based model of the ERD. 
The chemical model system used for this study is the production of butyl butyrate ( $\mathrm{BuBu})$, a volatile ester with a pleasant aroma, used in the flavor industry to create sweet fruity flavors similar to that of pineapple. This transesterification reaction of ethyl butyrate (EtBu) with $n$ butanol $(\mathrm{BuOH})$ forming ethanol $(\mathrm{EtOH})$ uses lipase as catalyst (eq. 1). This chemical system is suitable for RD according to the feasibility scheme of Shah et al. (2012) [13].

$\mathrm{EtBu}+\mathrm{BuOH} \rightleftharpoons \mathrm{BuBu}+\mathrm{EtOH}$

Among the enzymes used industrially, the B-component lipase from the yeast Candida antarctica (CalB) is a particularly efficient and robust lipase catalyzing a large diversity of organic reactions, including transesterification [14]. The enzymatic catalyst is immobilized in two different configurations, either as enzyme beads sandwiched in structured packing or as enzyme containing silica-gel based coating applied onto structured packing (Figure 1). Both catalytic packings are introduced in the pilot-scale RD column at the Laboratory of Fluid Separations, TU Dortmund University, for experimental investigation.

A comprehensive rate-based model is extended from the former developed rate-based model [15], incorporating mass and energy transfer, packing properties and the reaction kinetics. The main approach is to use "offline" measurement of kinetics and thermodynamics at lab scale together with hydrodynamic investigations of the influence of enzyme as beads or as coating in a binary non-reactive system. All these models are afterwards incorporated into one ratebased model. This model allows analyzing the experimental results to gain more insights into the experiments. Therefore, a sensitivity analysis was performed to efficiently identify sensitive process and design variables as literature examples show [16-18], which can be used for future improvement as well as enable efficiently the identification of a feasible operating window.

\section{Problem statement}

For the evaluation of ERD processes, reliable process models are needed to provide predictions of operating states, scale-up possibilities and production cost calculations. To fill this gap, we propose to establish such a model on a fundamental basis of experiments as described in a recent publication [19]. The steps to an evaluation of this technology are: 1) collection of fundamental data (and experiments), 2) identification of an operating window, 3) development of a mathematical model, 4) model-based process analysis, 5) equipment-based experiments, 6) model validation and 7) optimization of the process. 
The collection of fundamental data including property data [20] and the reaction kinetics [21] was presented recently. In this paper, we address the investigations of packing properties, we identify the operating window and we develop a mathematical model, followed by experiments which were carried out in a pilot-scale ERD column and a conventional distillation column. The aim is to propose an accurate rate-based model that describes ERD and to provide an experimental basis to prove the feasibility of ERD processes. The packing properties and correlations like hold-up, mass transfer and specific surface area, are required, but not available for the coated packing used in this study and are therefore investigated in a distillation set-up for a close-boiling binary system of iso-butanol (IBU) and $\mathrm{BuOH}$ and broadened afterwards to a rate-based model with the Maxwell-Stefan approach.

\section{Experimental}

In the experimental part of the work we address the materials and methods that were used to investigate the ERD, including descriptions of the ERD column and gas chromatographic (GC) analysis. A binary distillation system is used to ascertain properties of the used coated packing. The ERD experiments are conducted to show the feasibility of the ERD and to be able to validate the ERD model.

As both, reaction and separation, occur simultaneously in a RD unit, there must be a proper match between the temperatures and pressures required for reaction and separation translated into an overlapping window of the operating conditions [7]. Figure 2 illustrates the temperature and pressure range for the ERD process described in this study. This assessment is required for any experimental work. More details are provided in a subsequent section.

\subsection{Material \& Methods}

Chemicals: Table 1 provides the list of used chemicals, including the substance name, its purity and the producer, as well as the application area.

Distillation column: Figure 3 shows the distillation column which is used at the Laboratory of Fluid Separations, TU Dortmund University (5.12/5.16 m packed height, $12 \mathrm{~m}$ total height, DN50 / $51 \mathrm{~mm}$ inner diameter, made of glass, 6 sections, 7 liquid distributors located in between the glass sections to prevent from maldistribution). For the immobilization of enzymes in the RD column, a method of choice is the coating of Sulzer BX ${ }^{\circledR}$ wire gauze packing with a sol-gel that contains entrapped enzymes [22]. The self-measured activity of the coating is $4 \cdot 10^{-5} \mathrm{~mol} \mathrm{BuBu}$ per second and gram of coating at $65{ }^{\circ} \mathrm{C}$ and a substrate ratio $\chi_{\mathrm{EtBu} / \mathrm{BuOH}}$ of 10 with a coating thickness of $40 \mu \mathrm{m}$. The coating covers not only the wires of 
the packing, but also seals the gaps between the wires [23]. However, the mass transfer features of the packing are modified which means that hydrodynamics and the mass transfer phenomena need to be experimentally investigated. Another method of choice is the immobilization of enzyme on a spherical acrylic polymer resin, namely enzyme beads. The enzyme beads (IMMCALB-T2-1000XL) have a diameter of approximately $1 \mathrm{~mm}$. The selfmeasured activity of the enzyme beads is $1.9 \cdot 10^{-4} \mathrm{~mol} \mathrm{BuBu}$ per second and gram of coating at $65{ }^{\circ} \mathrm{C}$ and a substrate ratio $\chi_{\mathrm{EtBu} / \mathrm{BuOH}}$ of 10 . These beads were incorporated in the structure of a Katapak-SP ${ }^{\circledR}$ structured packing. The mass transfer phenomena and hydrodynamics of the Katapak-SP ${ }^{\circledR}$ structured packing were already investigated with glass beads [24]. It is assumed that the usage of enzyme beads does not change the packing properties. Each column section is equipped with packing depending on the investigated task (see Table 2 for details). The height of a section equipped with Katapak-SP ${ }^{\circledR}$ structured packing is $1 \mathrm{~m}$ high and a section equipped with Sulzer $\mathrm{BX}^{\circledR}$ is $0.96 \mathrm{~m}$ high.

The process control software used was Siemens Simatic ${ }^{\circledR}$ PCS 7. The vapor temperature measurement was performed using PT100 thermocouples that were installed below the liquid distributors and feed connections are at distributor 3 and 6 (at $3.2 \mathrm{~m}$ and at $0.96 \mathrm{~m}$ packed height of the column). For the binary distillation system only the feed at distributor 6 at $0.96 \mathrm{~m}$ packed height was used for both substrates. In the liquid distributors, liquid and vapor was by-passed, so they were not in contact with each other. The pilot-scale setup from Laboratory of Fluid Separations has been described in Holtbrügge et al. (2013) [10] in more detail and was used for the binary distillation experiments. For the experiments with enzyme beads, a new reboiler was installed. The heater was a heating rod, and the level was controlled by a level indicator controller and the bottoms pump flow rate was the manipulated variable. The bottom stream was connected to a cooler and send to the bottom product tank. Every $45 \mathrm{~min}$, three profiles involving eight samples were taken with a gas proof syringe from septa in liquid distributors, bottom and top streams. Nitrogen was used for inerting the column and also to prevent from superheating/heating delay in the reboiler. Glass wool was used as insulation ( $3 \mathrm{~cm}$ thick) followed by a power controllable electric heating wire and another layer of glass wool $(5 \mathrm{~cm}$ thick). The input power was set by a controller for which the set point was calculated from the vapor temperature measurement above and below the section of the heating wire (Figure 3).

The start-up and shut-down procedure was in accordance with Keller et al. (2012) [25]. For a faster shut down, the cooled bottom stream was pumped back to the reboiler. Data reconciliation was performed for the experiments in order to close the mass balance by means 
of adapting distillate and bottom compositions as well as mass flows within their experimentally determined error range.

GC analysis: An Agilent HP5 column (30 m length, inner diameter $0.32 \mathrm{~mm}$, and $0.25 \mu \mathrm{m}$ film thickness) was employed to determine the composition of the liquid samples for the binary and the transesterification system. The analytical method took $5.1 \mathrm{~min}$ per measurement. The initial temperature was $353 \mathrm{~K}$ which was held for one minute. Afterwards the temperature was increased with a temperature ramp of $4 \mathrm{~K} / \mathrm{min}$ up to $369 \mathrm{~K}$. The final temperature was held for $0.1 \mathrm{~min}$ before it was cooled down to the initial $353 \mathrm{~K}$ again. As an internal standard dibutyl ether was used for the transesterification samples and acetonitrile for the binary system.

\subsection{Binary Distillation System}

A system of close boiling components was selected, namely IBU and $\mathrm{BuOH}$ in order to measure the mass transfer and hydrodynamic performance. The main influencing parameter of the packing in a rate-based / Stefan-Maxwell approach is the $a_{\mathrm{i}}$ (interfacial area), which equals the specific surface area of the packing. For the enzyme coated packing, the coating covers the gaps of the packing's wire mesh and therefore changes $a_{\mathrm{i}}$ which was not yet described. For the liquid hold-up, a hold-up correlation was established recently [23]. This is a valid assumption because a liquid film is still formed although the packing might now behave as a sheet metal packing.

The description of the binary distillation experiments was reported recently [23]. Table 3 provides the experimental plan summing up four experiments with conventional packing and six experiments with coated packing. The conventional packing was used to check the model accuracy, and to prove that the model is capable to predict the experiments, as well as to make a comparison with the coated packing performance. In order to estimate the interfacial area the concentrations in the distributors were analyzed and compared with the model. Finally, the interfacial area was adjusted in the model to match the concentrations in the column.

For the validation of the mass transfer model, the experiments were carried out under total reflux with a varying reflux mass flow, generating different values for F-factor and liquid velocity. The feed was added at $0.96 \mathrm{~m}$ above the reboiler with a composition of $10 \mathrm{wt} \%$ IBU and $90 \mathrm{wt} \% \mathrm{BuOH}$ and a mass flow of $4 \mathrm{~kg} / \mathrm{h}$. A stream with the same properties was withdrawn from the bottom. This set-up helped to keep a constant amount of substance inside the distillation column, despite the sample taking. 


\subsection{Enzymatic Reactive Distillation}

The experimental plan for the ERD using enzyme beads (EB) and coated packing (CP) is given in Table 4 and conveniently visualized in Figure 4. Two experiments of ERD using coated packing are carried out to show its feasibility. The nine EB experiments represent a broader range of operating parameters. The height of the reactive section in case of $\mathrm{CP}$ is $1.92 \mathrm{~m}$ and in the case of EB it is $1.00 \mathrm{~m}$. The start-up procedure to reach the steady-state condition is the following. In this way, it was guaranteed that the enzyme's temperature limitation of $343 \mathrm{~K}$ is not exceeded.

- The experiment was started at atmospheric pressure with a high amount of ethanol in reboiler and liquid distributors.

- When first vapor was condensed at the column head, the pressure was steadily decreased and $\mathrm{EtBu}$ and $\mathrm{BuOH}$ was feeded through the side inlets no 3 and no 5 (Figure 3).

- The procedure according to Keller et al. (2012) for choosing desired set-points for the operating parameters (e.g. mass flows and distillate-to-feed-ratio) was followed [25].

Higher temperatures for the enzyme seem to be possible, but are probably associated with less stability. The mass of dry enzyme beads for the experiments is $56 \mathrm{~g} / \mathrm{m}$ packing while the mass of coating on the packing is $40 \mathrm{~g} / \mathrm{m}$ as the average amount of coating measured before and after the coated packing experiments. Note that, the mass per meter is not an indicator for the actual amount of enzyme inside or on the packing, since the coating mainly consists of solgel. The activity of the immobilizates was compared in a recent study [21]. To prevent the enzyme beads from repetitive shrinkage and swelling and therefore breakage, cold overflow was turned on twice a day for approximately $1 \mathrm{~h}$ to wet the enzyme beads inside the column. The shrinkage and swelling effect was less pronounced and could therefore be neglected. For all the experiments, a high amount of EtBu needs to be maintained in the reactive section since $\mathrm{BuOH}$ is inhibiting the enzyme. Three influencing operating variables, namely distillateto-feed-ratio, reflux ratio and substrate ratio in form of changing feed streams have been investigated.

\section{Results and Discussion}

In this section, the experimental results and the utilized model for rate-based simulations of ERD and binary distillation are described. This model was extended with physical properties of the used components [20] and kinetic data based on a recent publication [21]. Furthermore, the operating window is described in which the ERD is feasible for experimental 
investigations and simulation. The final subsection of this chapter demonstrates the validation of the ERD model by comparing the model with experimental results.

\subsection{Model Description}

Aspen Custom Modeler ${ }^{\circledR}$ (ACM) was used for the rate-based simulations of the ERD process, building upon the generic RD model developed at Laboratory of Fluid Separations, TU Dortmund University - already reported in literature [15]. In recent studies the model was successfully used to accurately predict or reproduce experimental operating points for the synthesis of dimethyl carbonate and propylene glycol [10], for $n$-propyl propionate synthesis [11] and for $n$-butyl acrylate production [26]. A first modeling study on the ERD for a chiral chemical system was recently published [19]. In general, the model describes a distillation column including the reboiler, condenser, column sections and the liquid distributors. It includes the MERSHQ equations [27], while the physical property data from Aspen Properties ${ }^{\circledR}$ needs to be added. If a reaction is considered, then the kinetic data can be seamlessly implemented.

In our study, Stefan-Maxwell correlations were used to describe the diffusional transport processes with the effective diffusion coefficients estimation based on the Aspen procedure. For the conventional Sulzer $B X^{\circledR}$ packing the specific surface area of $a_{\mathrm{i}}=492 \mathrm{~m}^{2} / \mathrm{m}^{3}$ is provided by the vendor [28]. The mass transfer and hold-up correlations are taken from literature [29-31]. For the coated packing a new value for the specific surface area was determined within this work. The packing data for the Katapak-SP ${ }^{\circledR}$ packing was reported in literature as well [24].

Physical Property Data: UNIFAC Dortmund modified (UNIF-DMD) was selected as most suitable property model for this chemical system. More information about the vapor-liquidequilibrium (VLE) data and the property method are available in Heils et al. (2014) [20].

Kinetic Data: The kinetics of the transesterification of ethyl butyrate was investigated in a recent study [21]. Based on these experimental results we assumed that the catalyzed system is not mass transfer controlled so that the rate-determining step is the kinetic step. A lumped kinetic is used that comprises mass transfer and kinetics. For the enzyme coated packing a reduced ordered bi bi kinetic approach from Bisswanger [32] was employed (2). The kinetic parameters for the coated packing are presented in Table 5 . The term including $K_{\mathrm{m}, \mathrm{BuOH}}$ is cancelled out, since it equals zero. 
$v=\frac{v_{\max } \cdot[\mathrm{BuOH}][\mathrm{EtBu}]}{K_{i, B u O H} \cdot[E t B u]+K_{m, E t B u} \cdot[\mathrm{BuOH}]+K_{m, B u O H} \cdot[E t B u]+[B u O H][E t B u]}$

For enzyme beads a simplified steady-state approximation of the Ping-Pong Bi Bi-mechanism was utilized (3) [33,34]. The kinetic parameters are listed in Table 6.

$$
v=\frac{v_{f} \cdot v_{r} \cdot\left([\mathrm{BuOH}][\mathrm{EtBu}]-\frac{1}{K_{e q}}[\mathrm{BuBu}][\mathrm{EtOH}]\right)}{\frac{v_{f}}{K_{e q}}[\mathrm{BuBu}][\mathrm{EtOH}]+v_{r} \cdot[\mathrm{BuOH}][\mathrm{EtBu}]}
$$

The usage of two different approaches is explained in Wierschem et al. (2016) [21].

\subsection{Operating Window}

Figure 2 illustrates the temperature and pressure range where the ERD process operates. The temperature and pressure are linked by the VLE of the boiling system. The upper operational limits are at $343 \mathrm{~K}$ (as higher temperatures would lead to instability of the enzyme catalyst) and the corresponding maximum pressure of $70 \mathrm{kPa}$. Similarly, the lower limits are $323 \mathrm{~K}$ (lower temperatures meaning reduced reaction rates and low conversion) and about $10 \mathrm{kPa}$ (lower pressures are technically still possible, but require much larger equipment size). The operating window is similar to the ones reported for chemical systems catalyzed by a thermally unstable ion-exchange resin catalyst [35].

\subsection{Binary Distillation System}

In the first part we demonstrate the model accuracy for the system of IBU and BuOH with the help of the experiment Con_D2 (Table 3). In this case, the conventional Sulzer BX ${ }^{\circledR}$ packing is used, for which data from literature is available. The model accuracy validation can be observed in Figure 5 that shows the composition and temperature profiles resulting from the simulation (lines) along with experimental results (markers). The measured values match the simulated results very well, indicating that the model can describe the mass and heat transfer and hydrodynamics in a very accurate manner. This can be stated for all four experiments using the conventional Sulzer $\mathrm{BX}^{\circledR}$ packing.

Figure 6 exemplarily shows the concentration and temperature profiles of the binary distillation with coated packing for the experiment CP_D1. By means of this data, the specific surface area $a_{\mathrm{i}}$, of the coated packing was estimated to $350 \mathrm{~m}^{2} / \mathrm{m}^{3}$. The match between the 
simulation and experimental results is remarkable good (only maximally $0.043 \mathrm{~mol} / \mathrm{mol}$ deviation). The performance of the model to describe the column profiles is equally accurate for the other distillation experiments with coated packing. The lower value for the specific surface area of the coated packing (less than $72 \%$ of the value reported for the conventional Sulzer $B X{ }^{\circledR}$ packing) means that the mass transfer rate is worse than for the conventional packing - as lower the specific surface area, the smaller the mass transfer flow between vapor and liquid phase. This is underpinned by the higher measured HETP values (20\% [9] up to $40 \%$ [23] increase for coated packing), which imply worse mass transfer.

\subsection{Enzymatic Reactive Distillation}

In this section the experimental results and model validation for the ERD experiments are described. Figure 7 shows the experimental and simulated composition and temperature profiles in the column for the representative experiment EB3 (see operating conditions listed in Table 4). The operating parameters of the RD experiment were the same as in the simulation. Since the enzyme beads are more active compared to coated packing, a shorter reactive section is applied for the experiments with the enzyme beads $(1 \mathrm{~m}$, Table 2$)$. The excess of $\mathrm{EtBu}$ in the feed streams corresponds with the high amount of EtBu in the column profile. The excess is needed due to inhibition of the enzyme with $\mathrm{BuOH}$. The experimental conversion of $\mathrm{BuOH}$ and $\mathrm{EtBu}$ was $93.8 \%$ and $25.9 \%$ respectively. There is an excellent match between the measured values and the simulation results (only maximally $0.071 \mathrm{~mol} / \mathrm{mol} \mathrm{deviation} \mathrm{for} \mathrm{EtBu,} 0.05 \mathrm{~mol} / \mathrm{mol}$ deviation for $\mathrm{BuBu}$ and $0.023 \mathrm{~mol} / \mathrm{mol}$ for $\mathrm{EtOH}$ and $\mathrm{BuOH})$. A similar high accuracy has been observed for all the other experiments with enzyme beads (EB1-EB9).

The reproducibility of the experiments is required to check if the operation reveals high accuracy and if the same steady-state is attained. Furthermore, reproducibility is able to identify possible catalyst deactivation. Therefore, the experiments EB1 and EB8 were compared, which were carried out at equal operating conditions (see Table 4) to demonstrate the enzyme performance after approximately $80 \mathrm{~h}$ of distillation operation with hot overflowing liquid and $120 \mathrm{~h}$ of cold overflow (EB2-EB7). As a result, Figure 8 depicts the experiments EB1 and EB8 and their performance with a different stress for the enzyme beads. There is a slight change in the column profile and the conversion of $\mathrm{BuOH}$ is $95.5 \%$ and $95.2 \%$, respectively. These slight changes are more likely caused by slight differences in the operating conditions. We ascertain that the catalyst is very stable despite the stress from operation and is likely to be used over long time periods. 
Compared to the enzyme beads experiments, in case of coated packing the reactive section is longer $(1.92 \mathrm{~m})$. The activity of the coating is assuredly lower than the one of the enzyme beads. Hence, more reactive section height is needed for a reasonable conversion. The conversion of $\mathrm{BuOH}$ is $87.7 \%$ and of $\mathrm{EtBu}$ it is $24.2 \%$, which is slightly lower despite the higher reactive section. Figure 9 shows column composition and temperature profiles for experiment $\mathrm{CP} 2$. The mass of coating comprising enzyme in the experiment was determined to $40 \mathrm{~g} / \mathrm{m}$. Simulations with coated packing were not corresponding with the experimental results obtained for this mass of coating, which underlies the uncertainties associated with the coating procedure. Fluctuations in the mass of each structured packing can amount to $25 \%$. In addition coating can be lost in the process of installing and removing the packing. Particles of the coating where found in the liquid distributors, which are located between the sections of the column. The increased reactive surface due to this particle formation can again result in a higher reaction rate. Therefore, improving the coating procedure and washing step of the coated packing, as well as improving its stability are important measures to reduce the fluctuations and thus reduce the uncertainty. Despite of this, maldistribution on the packing can occur and lead to differences in the results for pilot-scale ERD experiments and small labscale experiments for the determination of reaction kinetics. Thus, the mass of coating was changed to $65 \mathrm{~g} / \mathrm{m}$ in the model in order to satisfy the modeling results. For this mass of coating, the modeling results are very accurate except for slight mismatches for the amounts of $\mathrm{EtBu}$ and $\mathrm{BuOH}$ in the stripping section (only maximally $0.054 \mathrm{~mol} / \mathrm{mol}$ deviation for $\mathrm{EtBu}, 0.028 \mathrm{~mol} / \mathrm{mol}$ deviation for $\mathrm{BuBu}$ and $0.004 \mathrm{~mol} / \mathrm{mol}$ for $\mathrm{EtOH}$ and $0.032 \mathrm{~mol} / \mathrm{mol}$ for $\mathrm{BuOH})$. A similar accuracy holds true for the other experiment with coated packing (CP1). For both cases, coated packing and enzyme beads, the model is capable of reproducing the experiments with high accuracy and it is therefore validated.

\section{Sensitivity Analysis}

A local sensitivity analysis is presented for the purpose to identify the sensitivity of important operating and design parameters on the performance of the ERD utilizing the validated ERD model. Therefore an industrial process is considered with a total feed stream of $1250 \mathrm{~kg} / \mathrm{h}$, a reactive section height of $4.0 \mathrm{~m}$ consisting of coated packing and a total height of $7.2 \mathrm{~m}$ with a diameter of $1 \mathrm{~m}$. Table 7 depicts the operating and design variables for the nominal operating point. One of the operating or design variables is changed during the analysis whereas the other parameters are kept constant. Figure 10 shows the influence of the following operating variables on conversion: substrate ratio (reactants ratio), distillate-to-feed ratio (D/F), reflux 
ratio (RR) and the column head pressure. It should be noted that the conversion increases fast with the substrate ratio when raised to a value of 1.5 , but then it remains rather constant in the range of $90 \%$ for $\mathrm{BuOH}$ for further increased substrate ratios and decreases for the conversion of ethyl butyrate. The reason for this behavior is the negative effect of an excess of butanol which inhibits the enzyme catalyst. The conversion of $\mathrm{BuOH}$ initially rises with increasing $\mathrm{D} / \mathrm{F}$ ratios since remaining substrate is recycled back to the reactive section. For D/F ratios higher than 0.55, a drop in the conversion of $\mathrm{BuOH}$ is observed which is likely due to the higher product reflux shifting the equilibrium to the substrate side. A mass-based RR of around $5 \mathrm{~kg} / \mathrm{kg}$ ensures high conversion (90\%), but exceeding this RR value leads to a reduction in conversion - as more product returns to the ERD column. This is detrimental to the chemical equilibrium. The column head pressure has an effect that is actually related to the corresponding temperature: higher pressure means higher temperature of the boiling system which leads to higher reaction rates and ultimately higher conversion. The discontinuity of the pressure course at approximately $11.3 \mathrm{kPa}$ is possibly due to the vapor pressure of $\mathrm{BuOH}$, which is at this value for the column temperature of $338 \mathrm{~K}$. Therefore $\mathrm{BuOH}$ tends to go into the liquid phase for pressures above $11.3 \mathrm{kPa}$ and hence the reaction rate is increased.

The influence of the design parameters reactive section height, specific surface area and catalyst density in the column on the conversion is shown in (Figure 11). The higher the reactive section, the more enzyme is present and the more substrate is converted into product. The same phenomenon is obvious for the catalyst density, which is related to the amount of enzyme per column volume. If more enzyme could be added to the column, higher conversion rates could be gained. In case of the specific surface area, there is an optimum at approximately $200 \mathrm{~m}^{2} / \mathrm{m}^{3}$. Remarkably, the conversion of the substrates decreases for higher values, although a higher specific surface area should increase the product separation in the reactive section. This is still true, but also the substrates concentration in the reactive section changes. With a higher specific surface area mass transfer is increased and the concentration changes in the reactive section are more intense. This leads to a higher ratio of the substrates inside the reactive section. In a recent publication [21] it was shown that for greater values of around 5 for the substrate ratio $\chi_{\mathrm{EtBu} / \mathrm{BuOH}}$ the reaction rate is decreasing. Thus, a higher specific surface area leads to lower conversions. This could be different when applying the enzyme beads in the Katapak-SP ${ }^{\circledR}$ structured packing.

The sensitivity analysis shows that high conversion rates can be reached in many different ways changing the operating and design parameters. Due to the excess of EtBu over $\mathrm{BuOH}$ 
the conversion of $\mathrm{BuOH}$ is always higher, whereas an excess of $\mathrm{BuOH}$ is not favorable. To find the optimum set of operating and design parameters, an optimization will be performed in the future.

\section{Conclusions}

The pilot-scale experimental validation of an Enzymatic Reactive Distillation (ERD) process for the synthesis of butyl butyrate has been successfully proven. Applying enzymes as catalyst in a continuous reactive distillation (RD) column equipped with two types of packing (immobilized enzyme beads and coated packing) was shown to be feasible. During the operation the enzyme was stable without activity loss. Moreover, the developed rate-based model has been successfully validated on the basis of the experimental data. By modifying the thermodynamic model and the reaction kinetics the ERD model can quickly be adapted to other chemical systems and can be used to analyze the ERD process and perform design studies within different project phases.

\section{Acknowledgements}

The research leading to these results has received funding from the Ministry of Innovation, Science and Research of North Rhine-Westphalia in the framework of CLIB-Graduate Cluster Industrial Biotechnology, contract no: 314 - 10800108 and the European Community's Seventh Framework Programme under grant agreement no. FP7-NMP-2012-309874. The authors also thank Sulzer Chemtech Ltd. for the provision of column packing and Katya Georgieva for her help with the preparation of the coatings. 


\section{References}

[1] D.J. Pollard, J.M. Woodley, Biocatalysis for pharmaceutical intermediates: the future is now, Trends Biotechnol. 25 (2007) 66-73.

[2] M. Breuer, K. Ditrich, T. Habicher, B. Hauer, M. Keßeler, R. Stürmer, T. Zelinski, Industrial Methods for the Production of Optically Active Intermediates, Angew. Chem. Int. Ed. 43 (2004) 788-824.

[3] P. Tufvesson, W. Fu, J.S. Jensen, J.M. Woodley, Process considerations for the scale-up and implementation of biocatalysis, Food Bioprod. Process. 88 (2010) 3-11.

[4] G. Lye, J.M. Woodley, Application of in situ product-removal techniques to biocatalytic processes, Trends Biotechnol. 17 (1999) 395-402.

[5] P. Poechlauer, J. Manley, R. Broxterman, B. Gregertsen, M. Ridemark, Continuous Processing in the Manufacture of Active Pharmaceutical Ingredients and Finished Dosage Forms: An Industry Perspective, Org. Process Res. Dev. 16 (2012) 1586-1590.

[6] S.D. Schaber, D.I. Gerogiorgis, R. Ramachandran, Evans, James M. B., P.I. Barton, B.L. Trout, Economic Analysis of Integrated Continuous and Batch Pharmaceutical Manufacturing: A Case Study, Ind. Eng. Chem. Res. 50 (2011) 10083-10092.

[7] P. Lutze, A. Górak, Reactive and membrane-assisted distillation: Recent developments and perspective, Chem. Eng. Res. Des. 91 (2013) 1978-1997.

[8] V.M. Balcão, A.L. Paiva, F. Xavier Malcata, Bioreactors with immobilized lipases: State of the art, Enzyme Microb. Technol. 18 (1996) 392-416.

[9] R. Heils, J.-H. Jensen, S. Wichert, N. Behrens, M. Fabuel-Ortega, A. Liese, I. Smirnova, Enzymatic Reactive Distillation: Kinetic Resolution of rac -2-Pentanol with Biocatalytic Coatings on Structured Packings, Ind. Eng. Chem. Res. 54 (2015) 9458-9467.

[10] J. Holtbruegge, S. Heile, P. Lutze, A. Górak, Synthesis of dimethyl carbonate and propylene glycol in a pilot-scale reactive distillation column: Experimental investigation, modeling and process analysis, Chem. Eng. J. 234 (2013) 448-463.

[11] T. Keller, J. Muendges, A. Jantharasuk, C.A. Gónzalez-Rugerio, H. Moritz, P. Kreis, A. Górak, Experimental model validation for n-propyl propionate synthesis in a reactive distillation column coupled with a liquid-liquid phase separator, Chem. Eng. Sci. 66 (2011) 4889-4900.

[12] R. Baur, A.P. Higler, R. Taylor, R. Krishna, Comparison of equilibrium stage and nonequilibrium stage models for reactive distillation, Chem. Eng. J. 76 (2000) 33-47. 
[13] M. Shah, A.A. Kiss, E. Zondervan, de Haan, A. B., A systematic framework for the feasibility and technical evaluation of reactive distillation processes, Chem. Eng. Process. Process Intensif. 60 (2012) 55-64.

[14] E.M. Anderson, K.M. Larsson, O. Kirk, One Biocatalyst-Many Applications: The Use of Candida Antarctica B-Lipase in Organic Synthesis, Biocatal. Biotransform. 16 (1998) $181-204$.

[15] M. Klöker, E.Y. Kenig, A. Hoffmann, P. Kreis, A. Górak, Rate-based modelling and simulation of reactive separations in gas/vapour-liquid systems, Chem. Eng. Process. Process Intensif. 44 (2005) 617-629.

[16] K. Dems, Sensitivity Analysis in Thermal Problems-1: Variation of Material Parameters within a Fixed Domain, J. Therm. Stresses 9 (1986) 303-324.

[17] J. Vazquez-Arenas, L.E. Gimenez, M. Fowler, T. Han, S.-k. Chen, A rapid estimation and sensitivity analysis of parameters describing the behavior of commercial Li-ion batteries including thermal analysis, Energy Convers. Manage. 87 (2014) 472-482.

[18] Y. Zhang, M. Dubé, D. McLean, M. Kates, Biodiesel production from waste cooking oil: 2. Economic assessment and sensitivity analysis, Bioresource Technol. 90 (2003) 229_ 240.

[19] M. Wierschem, S. Boll, P. Lutze, A. Górak, Evaluation of the Enzymatic Reactive Distillation for the Production of Chiral Compounds, Chem. Ing. Tech. 88 (2016) 147157.

[20] R. Heils, A. Niesbach, M. Wierschem, D. Claus, S. Soboll, P. Lutze, I. Smirnova, Integration of Enzymatic Catalysts in a Continuous Reactive Distillation Column: Reaction Kinetics and Process Simulation, Ind. Eng. Chem. Res. 53 (2014) 1961219619.

[21] M. Wierschem, O. Walz, M. Termuehlen, A.-L. Specht, M. Skiborowski, Enzyme Kinetics for the Transesterification of Ethyl Butyrate with Enzyme Beads, Coated Packing and Ultrasound Assistance, Submitted for publication, Chem. Eng. Process. Process Intensif. (2016).

[22] R. Heils, A. Sont, P. Bubenheim, A. Liese, I. Smirnova, Integration of Enzymatic Catalysts in a Reactive Distillation Column with Structured Packings, Ind. Eng. Chem. Res. 51 (2012) 11482-11489.

[23] M. Wierschem, R. Heils, S. Schlimper, I. Smirnova, A. Górak, P. Lutze, Enzymatic Reactive Distillation for the Transesterification of Ethyl Butyrate: Model Validation and Process Analysis, in: K.V. Gernaey, J.K. Huusom, R. Gani (Eds.), 12th International 
Symposium on Process Systems Engineering and 25th European Symposium on Computer Aided Process Engineering, Elsevier, Amsterdam, 2015, pp. 2135-2140.

[24] E. Brunazzi, A. Viva, Experimental Investigation of Reactive Distillation Packing Katapak-SP 11: Hydrodynamic Aspects and Size Effects, in: E. Sørensen (Ed.), Distillation and Absorption 2006, Institution of Chemical Engineers, Rugby, 2006, pp. $554-562$.

[25] T. Keller, J. Holtbruegge, A. Górak, Transesterification of dimethyl carbonate with ethanol in a pilot-scale reactive distillation column, Chem. Eng. J. 180 (2012) 309-322.

[26] A. Niesbach, H. Kuhlmann, T. Keller, P. Lutze, A. Górak, Optimisation of industrialscale n-butyl acrylate production using reactive distillation, Chem. Eng. Sci. 100 (2013) $360-372$.

[27] R. Taylor, R. Krishna, Multicomponent mass transfer, Wiley, New York, 1993.

[28] Sulzer Chemtech Ltd, Structured packings for distillation, absorption and reactive distillation, 2003.

[29] J.L. Bravo, J.A. Rocha, J.R. Fair, Mass transfer in gauze packings, Hydrocarbon Process. 64 (1985) 91-95.

[30] J.A. Rocha, J.L. Bravo, J.R. Fair, Distillation columns containing structured packings: a comprehensive model for their performance. 1. Hydraulic models, Ind. Eng. Chem. Res. 32 (1993) 641-651.

[31] J.A. Rocha, J.L. Bravo, J.R. Fair, Distillation Columns Containing Structured Packings: A Comprehensive Model for Their Performance. 2. Mass-Transfer Model, Ind. Eng. Chem. Res. 35 (1996) 1660-1667.

[32] H. Bisswanger, Enzyme kinetics: Principles and methods, 2nd ed., Wiley-VCH, Weinheim, 2008.

[33] R. Garrett, C.M. Grisham, Biochemistry, 5th ed., Brooks/Cole, Cengage Learning, Belmont, CA, 2013.

[34] A.L. Paiva, D. van Rossum, F.X. Malcata, Kinetics of Lipase-mediated Synthesis of Butyl Butyrate in n-hexane, Biocatal Biotransformation 20 (2002) 43-51.

[35] C.S. Bildea, R. Győrgy, E. Sánchez-Ramírez, J.J. Quiroz-Ramírez, J.G. SegoviaHernandez, A.A. Kiss, Optimal design and plantwide control of novel processes for di-npentyl ether production, J. Chem. Technol. Biotechnol. 90 (2015) 992-1001. 


\section{Tables}

Table 1. Used chemicals and catalysts for ERD experiments, as well as gas chromatographic analysis (GC) and distillation experiments (D).

\begin{tabular}{lclc}
\hline Substance & $\begin{array}{c}\text { Purity } \\
(\mathbf{G C})[\%]\end{array}$ & Producer & Application Area \\
\hline Acetonitrile & 99.9 & VWR International GmbH & GC \\
$\mathrm{BuBu}$ & 99 & Alfa Aesar & GC \\
$n$-BuOH & 99 & abcr GmbH & ERD/D \\
$n$-BuOH & 99.9 & VWR International GmbH & GC \\
Coated packing & {$[-]$} & Sulzer Chemtech Ltd, & ERD/D \\
& & TU Hamburg & \\
Dibutyl ether & 99 & Alfa Aesar & GC \\
EtBu & 99 & Reincke \& Fichtner GmbH & ERD/GC \\
EtOH & 100 & VWR International GbmH & GC \\
IBU & 99.2 & Hanke \& Seidel & D \\
IMMCALB-T2-1000XL & {$[-]$} & ChiralVision BV. & ERD \\
\hline
\end{tabular}

Table 2. Pilot-scale column set-up for the various experimental investigations from top to bottom and the reactive section in the middle of the column. The higher the section number, the closer the section is to the bottom.

\begin{tabular}{ccccc}
\hline Section & Height $[\mathrm{m}]$ & Packing Con_D $^{\text {Packing CP/CP_D }}$ & Packing EB \\
\hline 1 & 0.96 & Sulzer BX $^{\circledR}$ & Sulzer BX $^{\circledR}$ & Sulzer BX $^{\circledR}$ \\
2 & 0.96 & Sulzer BX $^{\circledR}$ & Sulzer BX $^{\circledR}$ & Sulzer BX $^{\circledR}$ \\
3 & 0.96 & Sulzer BX $^{\circledR}$ & Coated Sulzer BX $^{\circledR}$ & Sulzer BX $^{\circledR}$ \\
4 & $0.96 / 1.00$ & Sulzer BX $^{\circledR}$ & Coated Sulzer BX $^{\circledR}$ & Katapak-SP $^{\circledR}$ \\
5 & 0.32 & Sulzer BX $^{\circledR}$ & Sulzer BX & Sulzer BX $^{\circledR}$ \\
6 & 0.96 & Sulzer BX & Sulzer BX $^{\circledR}$ & Sulzer BX $^{\circledR}$
\end{tabular}


Table 3. Experimental plan for the pilot-scale binary distillation experiments to verify model accuracy and coated packing properties (note: CP_D stands for the experiments with coated packing and Con_D for the conventional distillation experiments with Sulzer $\mathrm{BX}^{\circledR}$ packing). All experiments are carried out under full reflux, $4 \mathrm{~kg} / \mathrm{h}$ feed and a feed composition of $i$ so-butanol (IBU) $10 \mathrm{wt} \%$ and $n$-butanol (BuOH) $90 \mathrm{wt} \%$.

\begin{tabular}{lccc}
\hline Experiment No. & $\begin{array}{c}\text { F-factor } \\
{\left[\mathbf{P a}^{\mathbf{0 . 5}}\right]}\end{array}$ & $\begin{array}{c}\text { Reflux } \\
{[\mathbf{k g} / \mathbf{h}]}\end{array}$ & $\begin{array}{c}\text { Pressure } \\
{[\mathbf{k P a}]}\end{array}$ \\
\hline Con_D1 & 0.92 & 6.5 & 40 \\
Con_D2 & 1.39 & 7.1 & 20 \\
Con_D3 & 0.77 & 6.2 & 60 \\
Con_D4 & 0.94 & 6.6 & 40 \\
CP_D1 & 0.91 & 6.5 & 40 \\
CP_D2 & 1.37 & 7.0 & 20 \\
CP_D3 & 0.72 & 6.1 & 60 \\
CP_D4 & 0.96 & 6.7 & 40 \\
CP_D5 & 1.59 & 8.1 & 20 \\
CP_D6 & 1.18 & 6.0 & 20 \\
\hline
\end{tabular}

Table 4. Experimental plan for the pilot-scale ERD experiments (note: EB stands for the experiments with enzyme beads and $\mathrm{CP}$ for the experiments with coated packing).

\begin{tabular}{cccccc}
\hline $\begin{array}{c}\text { Experiment } \\
\text { No. }\end{array}$ & $\begin{array}{c}\text { DF } \\
{[\mathbf{k g} / \mathbf{k g}]}\end{array}$ & $\begin{array}{c}\text { RR } \\
{[\mathbf{k g} / \mathbf{k g}]}\end{array}$ & $\begin{array}{c}\text { EtBu feed } \\
{[\mathrm{kg} / \mathbf{h}]}\end{array}$ & $\begin{array}{c}\text { BuOH feed } \\
{[\mathbf{k g} / \mathbf{h}]}\end{array}$ & $\begin{array}{c}\text { Pressure } \\
{[\mathbf{k P a}]}\end{array}$ \\
\hline EB1 & 0.63 & 2.69 & 1.70 & 0.30 & 14.5 \\
EB2 & 0.40 & 2.69 & 1.70 & 0.30 & 14.5 \\
EB3 & 0.55 & 2.69 & 1.70 & 0.30 & 14.5 \\
EB4 & 0.70 & 2.69 & 1.70 & 0.30 & 14.5 \\
EB5 & 0.63 & 1.00 & 1.70 & 0.30 & 14.5 \\
EB6 & 0.63 & 5.00 & 1.70 & 0.30 & 14.5 \\
EB7 & 0.63 & 2.69 & 1.65 & 0.35 & 14.5 \\
EB8 & 0.63 & 2.69 & 1.80 & 0.20 & 14.5 \\
EB9 & 0.63 & 2.69 & 1.70 & 0.30 & 14.5 \\
CP1 & 0.50 & 3.90 & 3.40 & 0.60 & 14.5 \\
CP2 & 0.63 & 2.69 & 1.70 & 0.30 & 14.5 \\
\hline
\end{tabular}


Table 5. Kinetic parameters for coated packing kinetic model.

\begin{tabular}{ccc}
\hline Parameter & Value & Unit \\
\hline $\mathrm{v}_{\max }$ & 0.668 & {$\left[\mathrm{~mol} /\left(\mathrm{s} \cdot \mathrm{kg}_{\mathrm{cat}}\right)\right]$} \\
$\mathrm{K}_{\mathrm{m}, \mathrm{BuOH}}$ & 0 & {$[\mathrm{~mol}]$} \\
$\mathrm{K}_{\mathrm{m}, \mathrm{EtBu}}$ & 25.252 & {$[\mathrm{~mol}]$} \\
$\mathrm{K}_{\mathrm{i}, \mathrm{BuOH}}$ & 0.054 & {$[\mathrm{~mol}]$} \\
\hline
\end{tabular}

Table 6. Kinetic parameters for enzyme beads kinetic model.

\begin{tabular}{ccc}
\hline Parameter & Value & Unit \\
\hline$v_{\mathrm{f}}$ & $3.88 \cdot 10^{-5}$ & {$\left[\mathrm{~mol} /\left(\mathrm{s} \cdot \mathrm{kg}_{\mathrm{cat}}\right)\right]$} \\
$\mathrm{v}_{\mathrm{r}}$ & $5.82 \cdot 10^{-6}$ & {$\left[\mathrm{~mol} /\left(\mathrm{s} \cdot \mathrm{kg}_{\mathrm{cat}}\right)\right]$} \\
$\mathrm{K}_{\mathrm{eq}}$ & 1.077 & {$[\mathrm{~mol} / \mathrm{mol}]$} \\
\hline
\end{tabular}

Table 7. Nominal values of the parameters used in the sensitivity analysis.

\begin{tabular}{ccc}
\hline Operating variable & Value & Unit \\
\hline Total feed stream & 1250 & {$[\mathrm{~kg} / \mathrm{h}]$} \\
Reactive section height & 4 & {$[\mathrm{~m}]$} \\
Specific surface area & 350 & {$\left[\mathrm{~m}^{2} / \mathrm{m}^{3}\right]$} \\
Catalyst density & 31.88 & {$\left[\mathrm{~kg} / \mathrm{m}^{3}\right]$} \\
Substrate ratio $(\mathrm{EtBu} / \mathrm{BuOH})$ & 2.0 & {$[\mathrm{~mol} / \mathrm{mol}]$} \\
DF & 0.5 & {$[\mathrm{~kg} / \mathrm{kg}]$} \\
RR & 4.0 & {$[\mathrm{~kg} / \mathrm{kg}]$} \\
Column head pressure & 14.2 & {$[\mathrm{kPa}]$} \\
\hline
\end{tabular}




\section{Figure captions}

Figure 1. a) Scheme of Enzymatic Reactive Distillation with the catalyst implementations in the enzymatic reactive section, b) coated packing, c) Katapak-SP ${ }^{\circledR}$, d) enzyme beads to be filled into Katapak-SP ${ }^{\circledR}$.

Figure 2. Operating window of the Enzymatic Reactive Distillation for the transesterification of ethyl butyrate. It is limited by pressure and temperature constraints as well as by the components' vapor pressures.

Figure 3. Process flowsheet of the Enzymatic Reactive Distillation column at the Laboratory of Fluid Separations.

Figure 4. Experimental plan for the Enzymatic Reactive Distillation experiments with enzyme beads.

Figure 5. Model validation for the distillation system with conventional Sulzer $B X^{\circledR}$ packing for the experiment Con_D2. Simulated and experimental column profiles with molar fractions of the components (left) and vapor temperature T_v (right) with experimental values indicated as "exp".

Figure 6. Model validation for the distillation system with coated packing for the experiment CP_D1. Simulated and experimental column profiles with molar fractions of the components (left) and vapor temperature T_v (right) with experimental values indicated as "exp". A packing surface $a_{i}$ of $350 \mathrm{~m}^{2} \mathrm{~m}^{-3}$ results in a high accuracy to describe the experimental results with a rate-based model.

Figure 7. Simulated and experimental column profiles of experiment EB1 with molar fractions of the components (left) and vapor temperature T_v (right) for the Enzymatic Reactive Distillation with enzyme beads. The reactive section, the feed positions and the reboiler are highlighted. Experimental values are indicated with "exp". 
Figure 8. Reproduced experimental column profiles with molar fractions of the components (left) and vapor temperature T_v (right) for the Enzymatic Reactive Distillation with enzyme beads. The reactive section, the feed positions and the reboiler are highlighted. Experiments EB1 and EB 8 are compared, which present the same operating point.

Figure 9. Simulated and experimental column profiles with molar fractions of the components (left) and vapor temperature T_v (right) for the Enzymatic Reactive Distillation with coated packing. The reactive section, the feed positions and the reboiler are highlighted. Experimental values are indicated with "exp".

Figure 10. Sensitivity analysis of the substrate conversion for varying substrate ratio $(\mathrm{EtBu} / \mathrm{BuOH})$, distillate-to-feed-ratio $(\mathrm{D} / \mathrm{F})$, reflux ratio $(\mathrm{RR})$ and the column head pressure.

Figure 11. Sensitivity analysis of the substrate conversion for varying reactive section height, specific surface area and catalyst density in the column. 


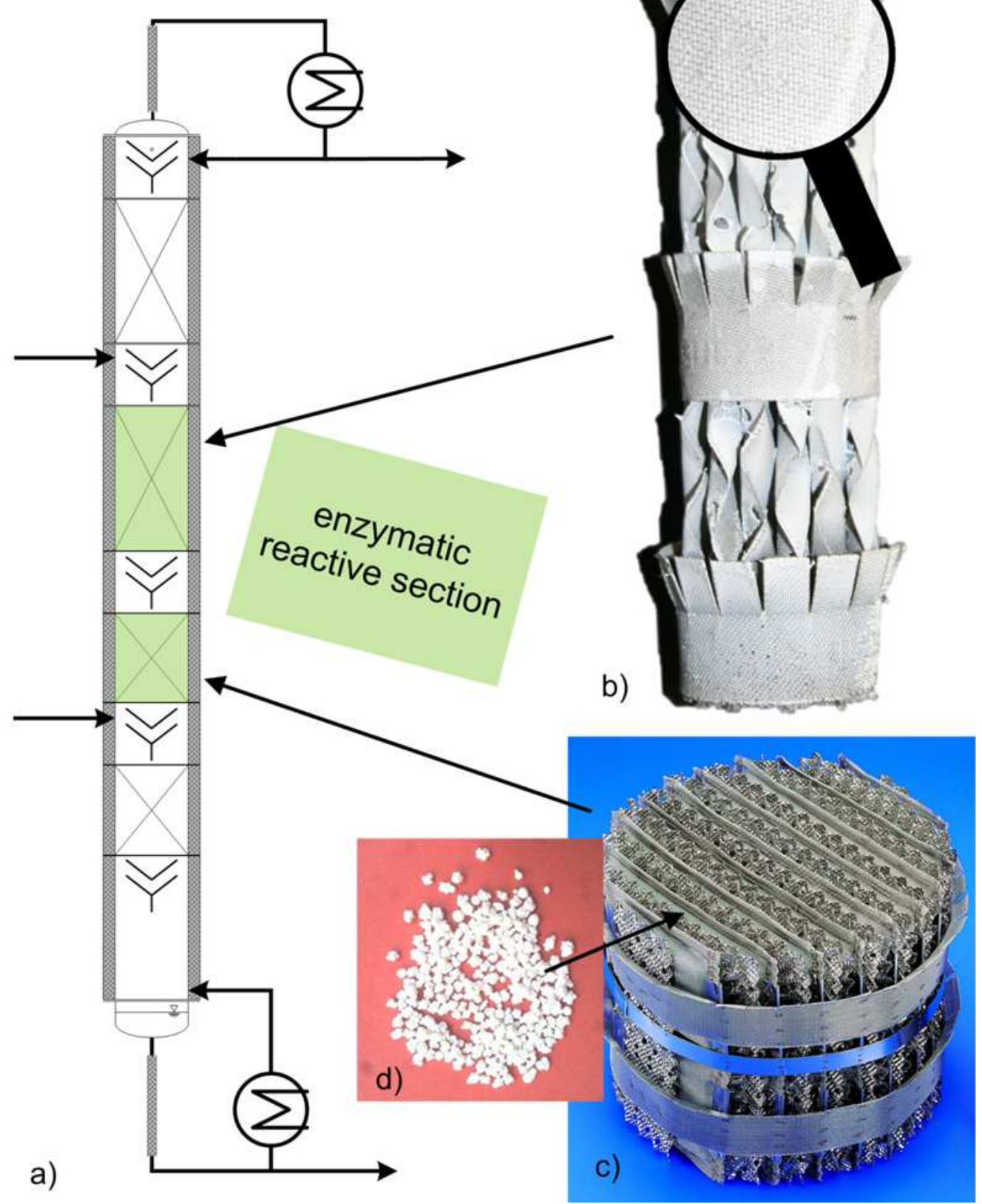

Figure 1 


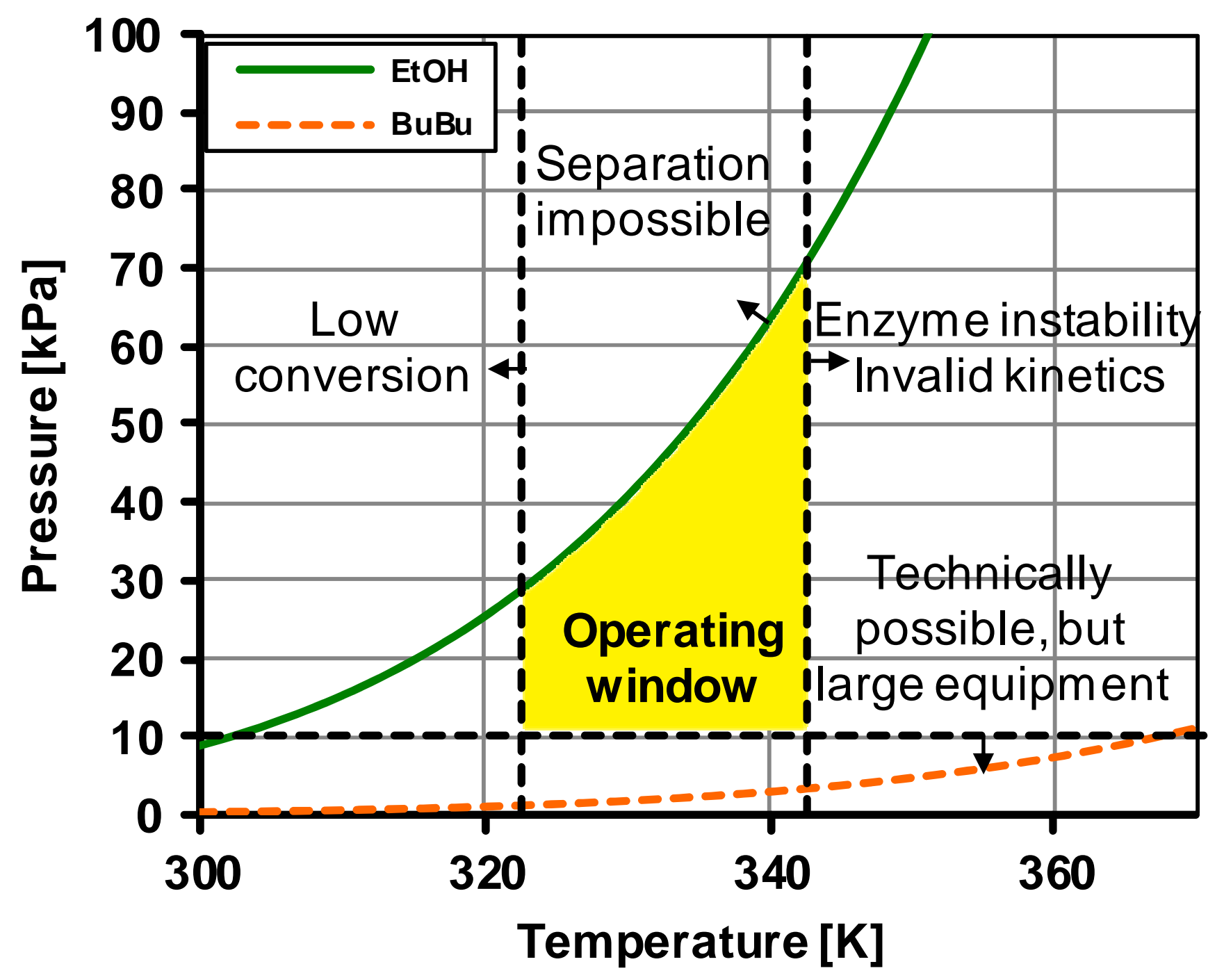


Pilot-scale RD (TUDo)

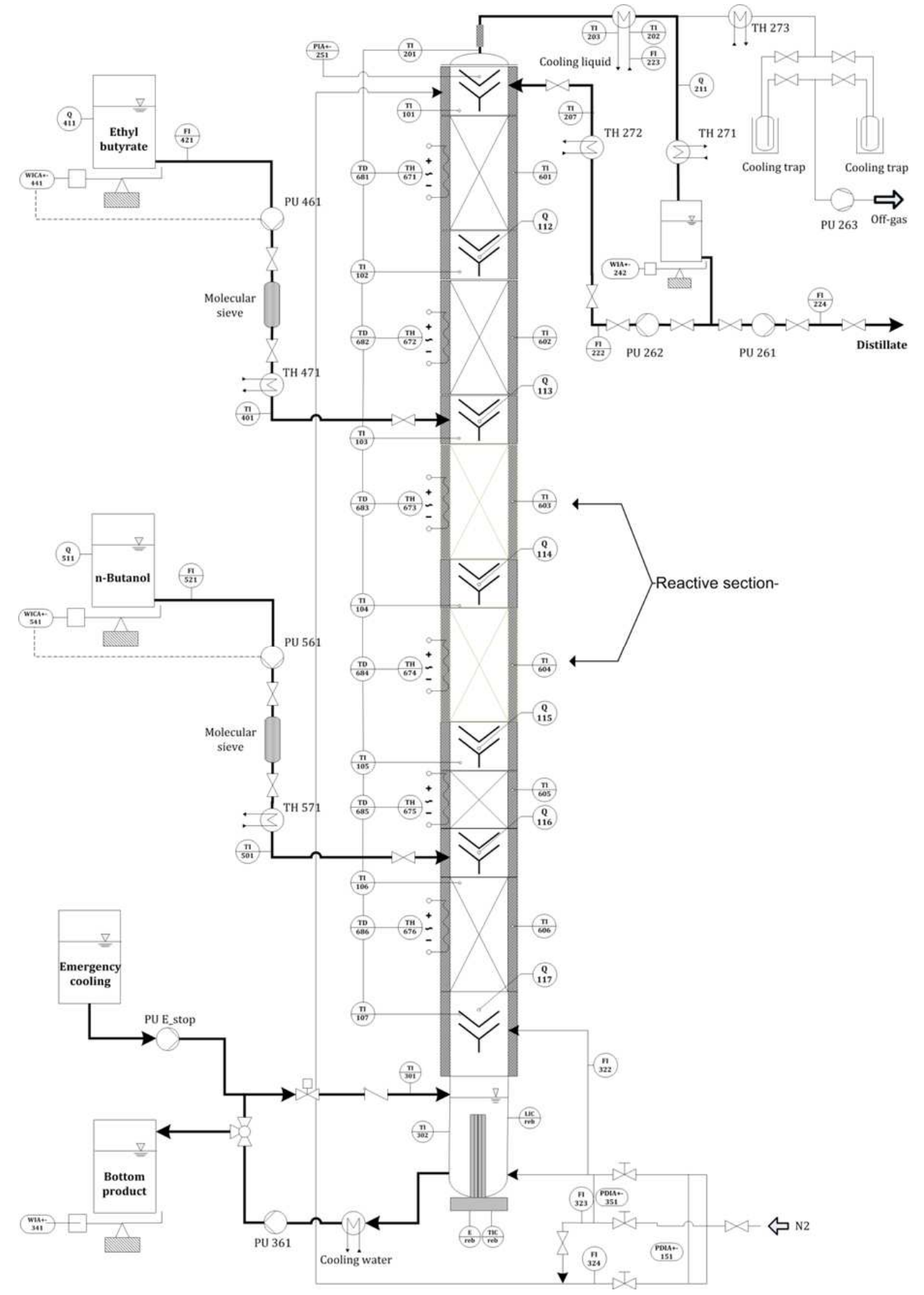

Figure 3 


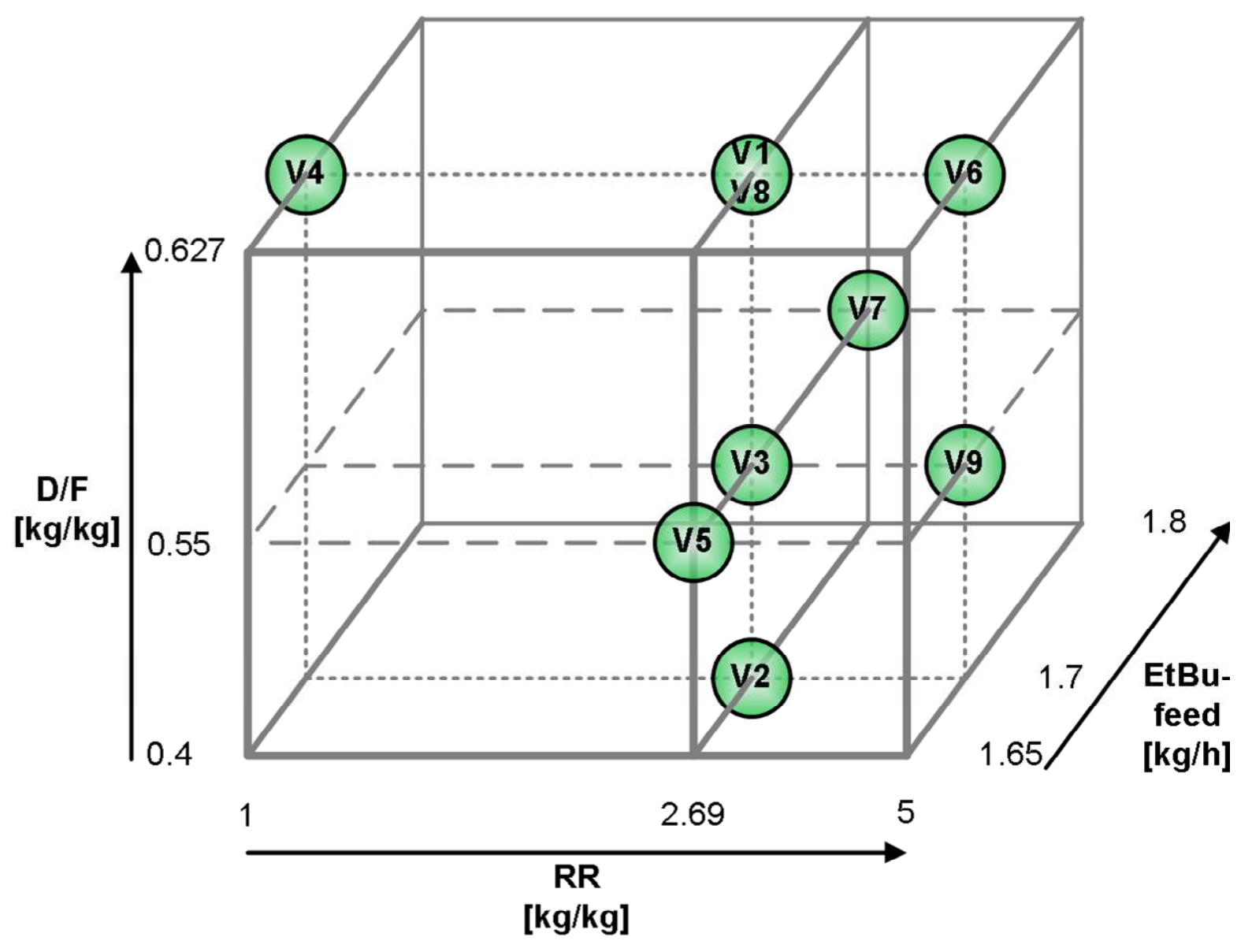



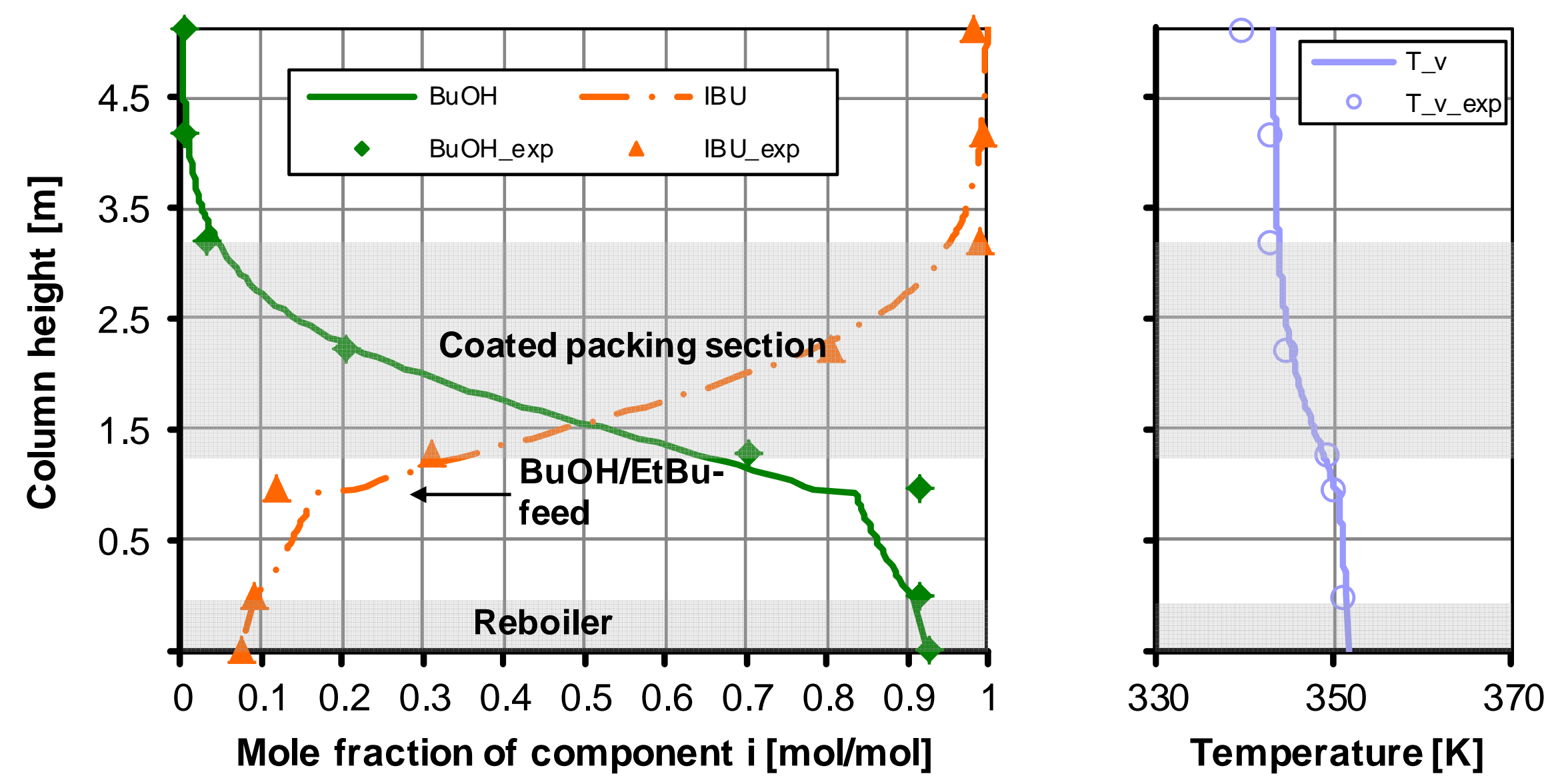

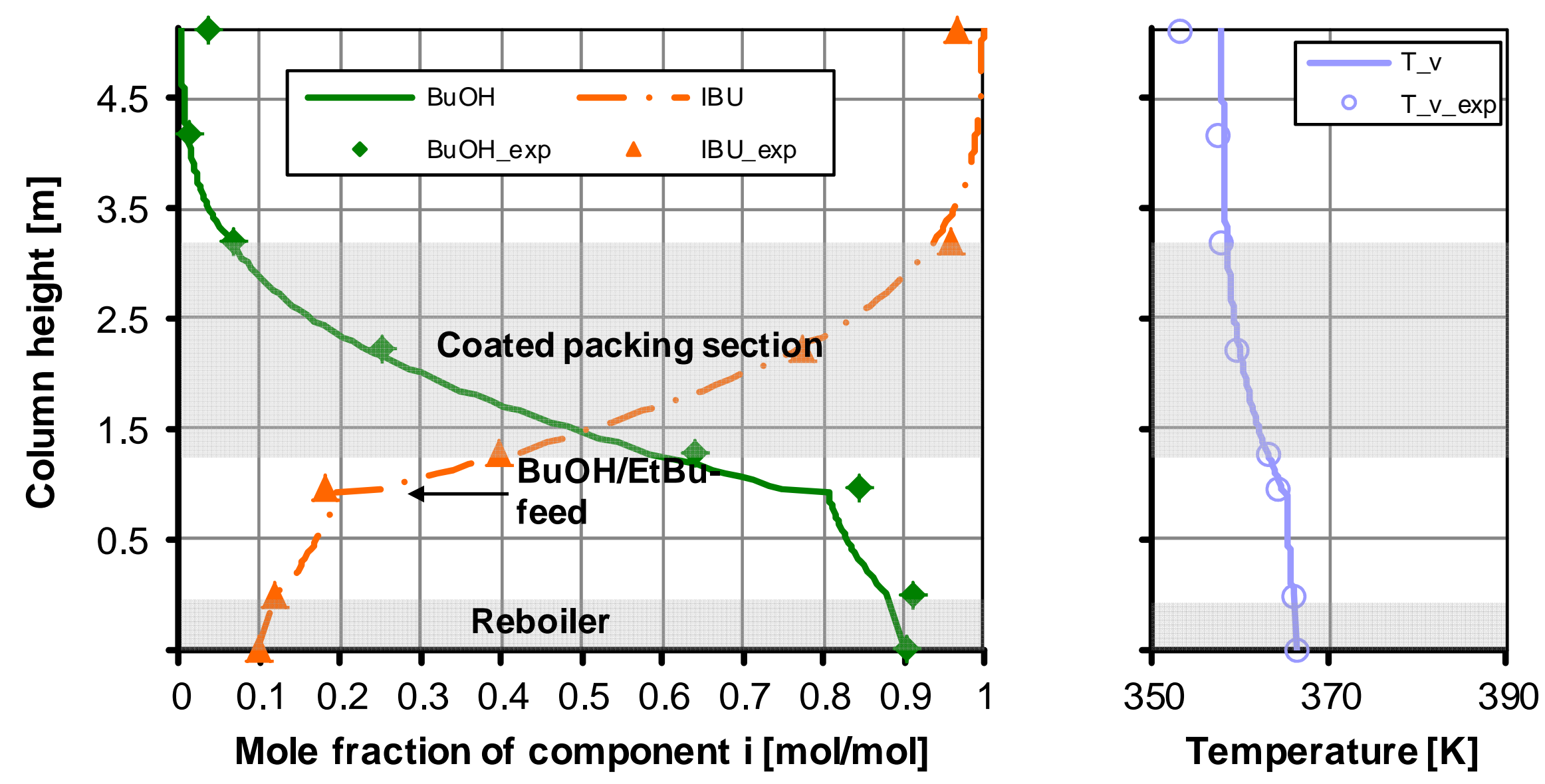

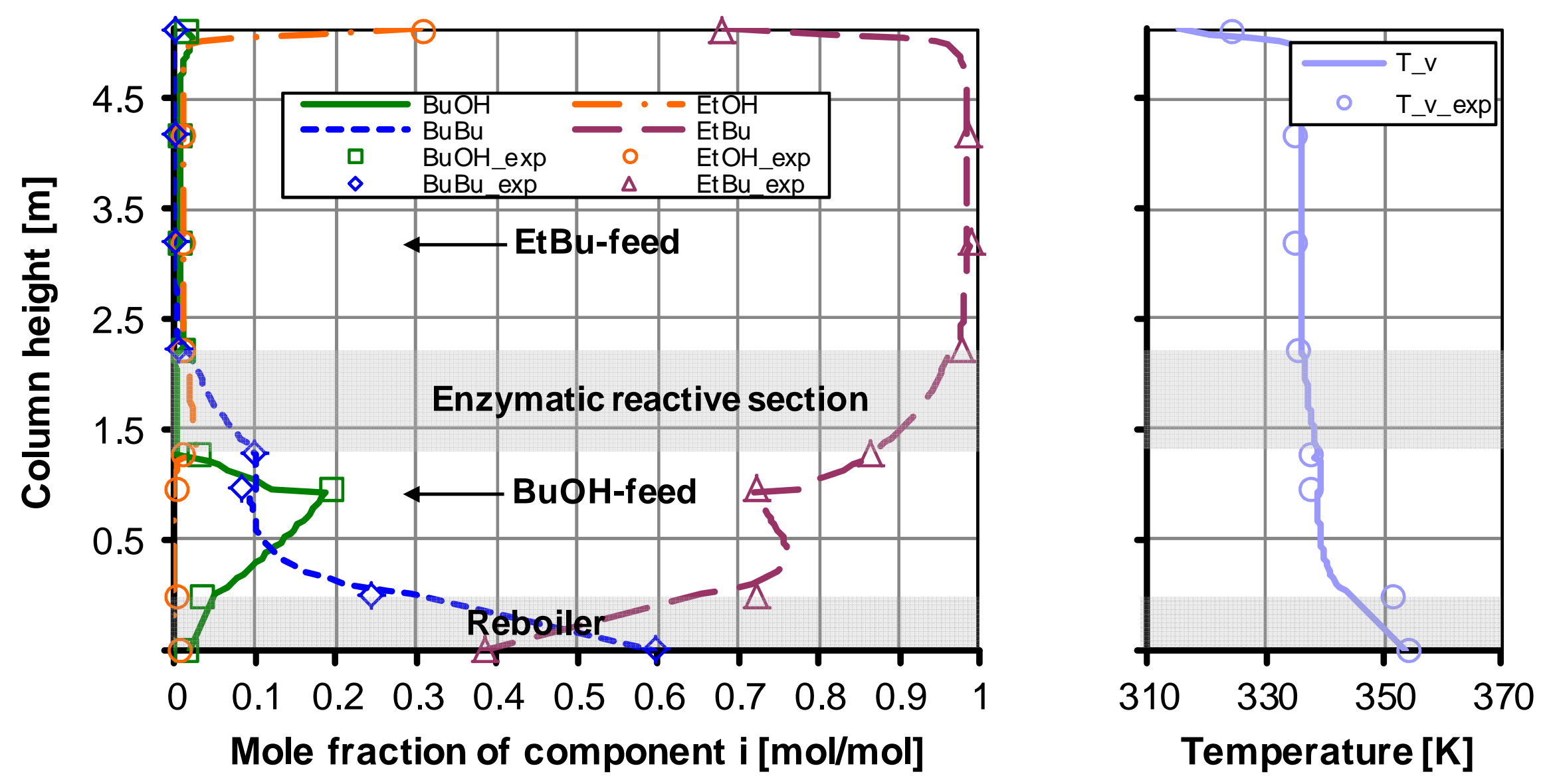

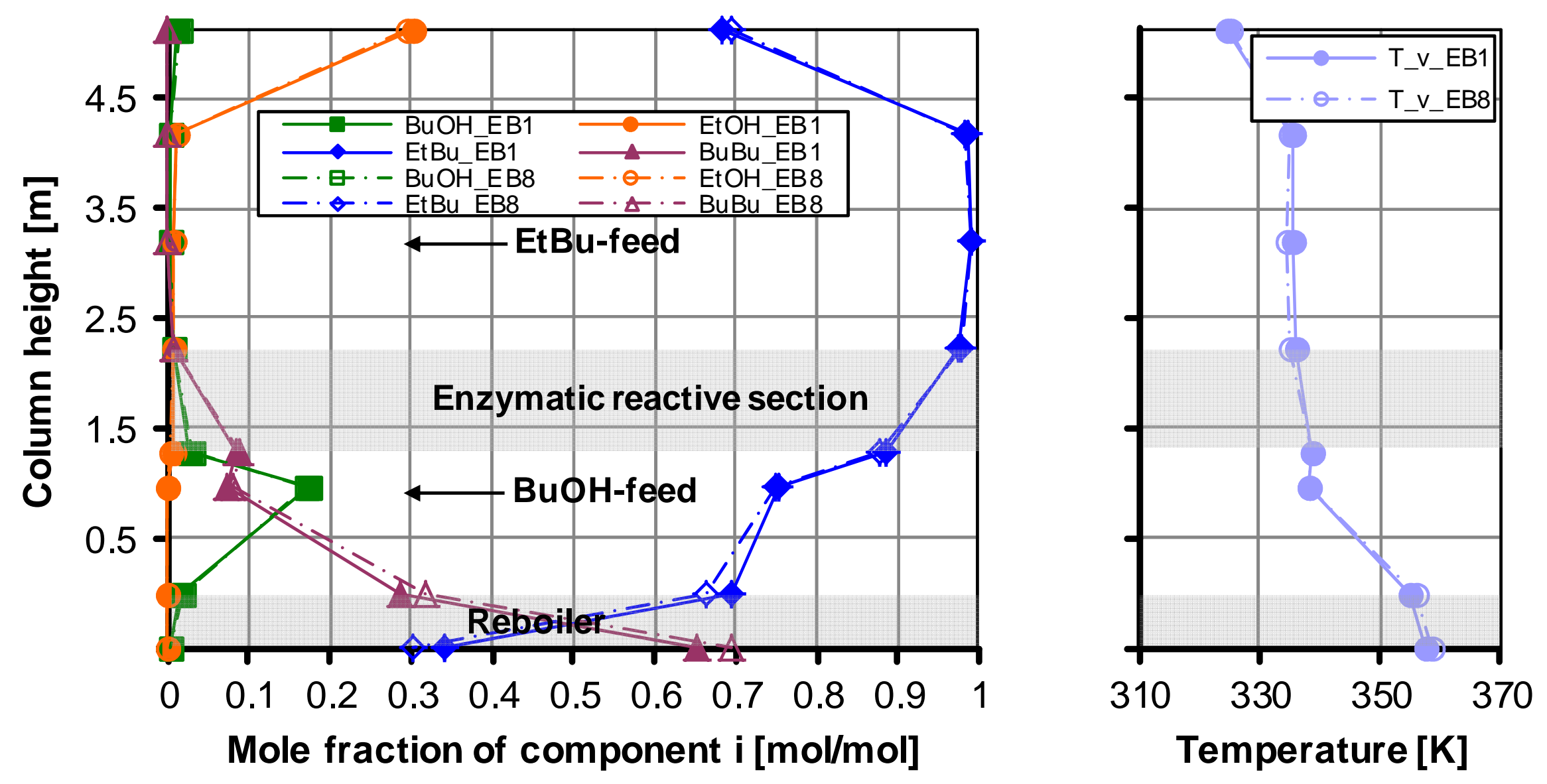

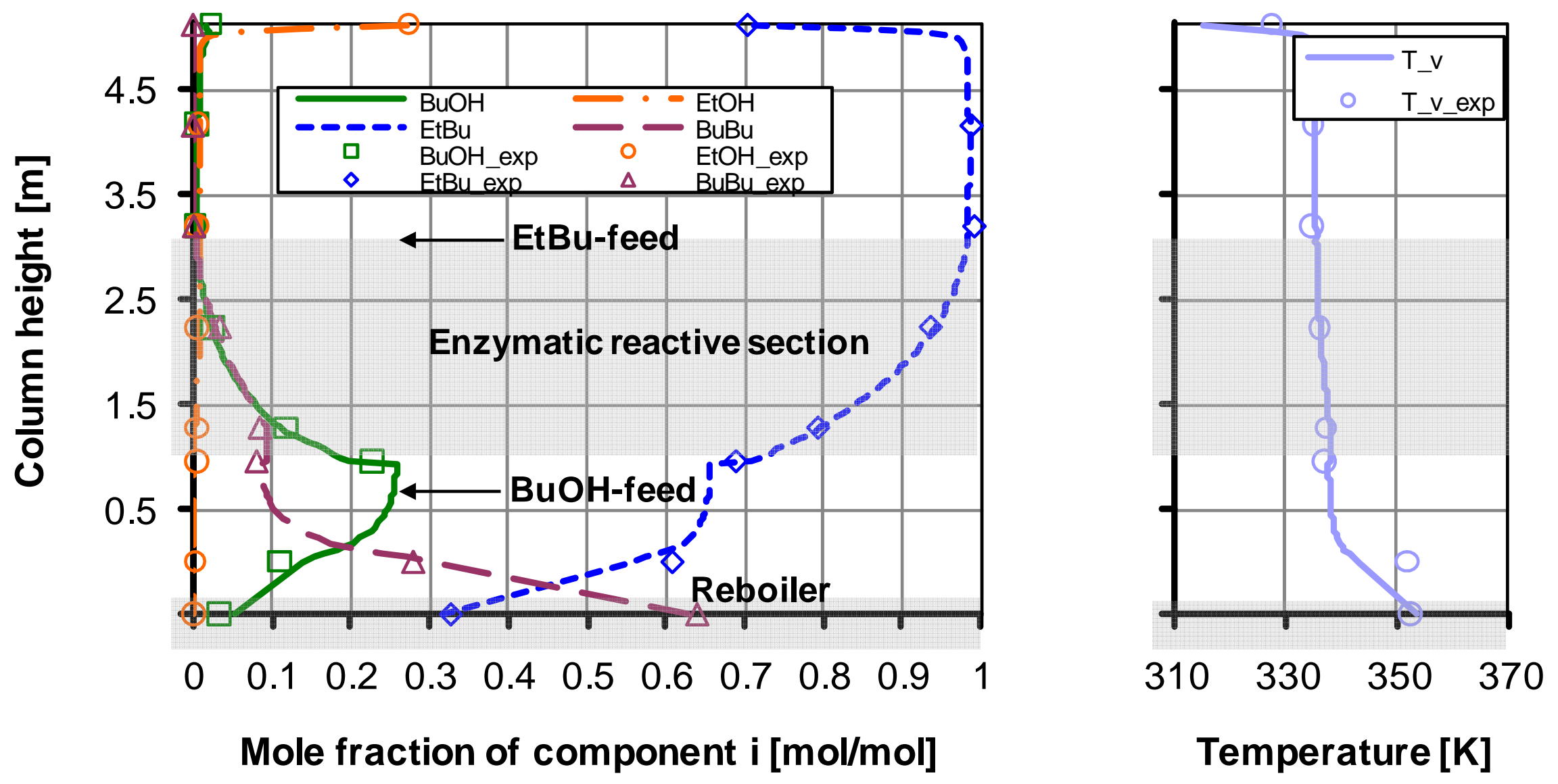

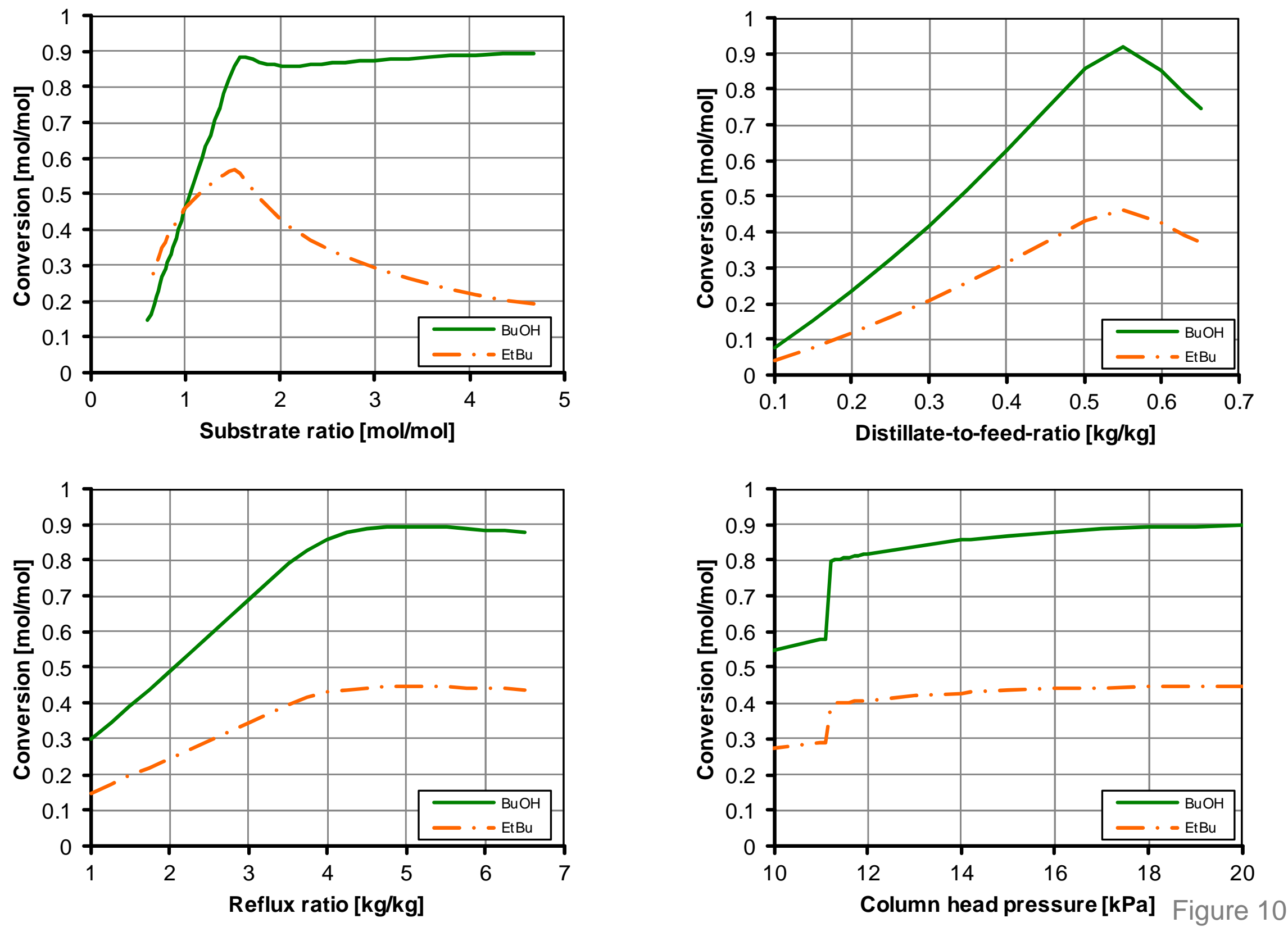

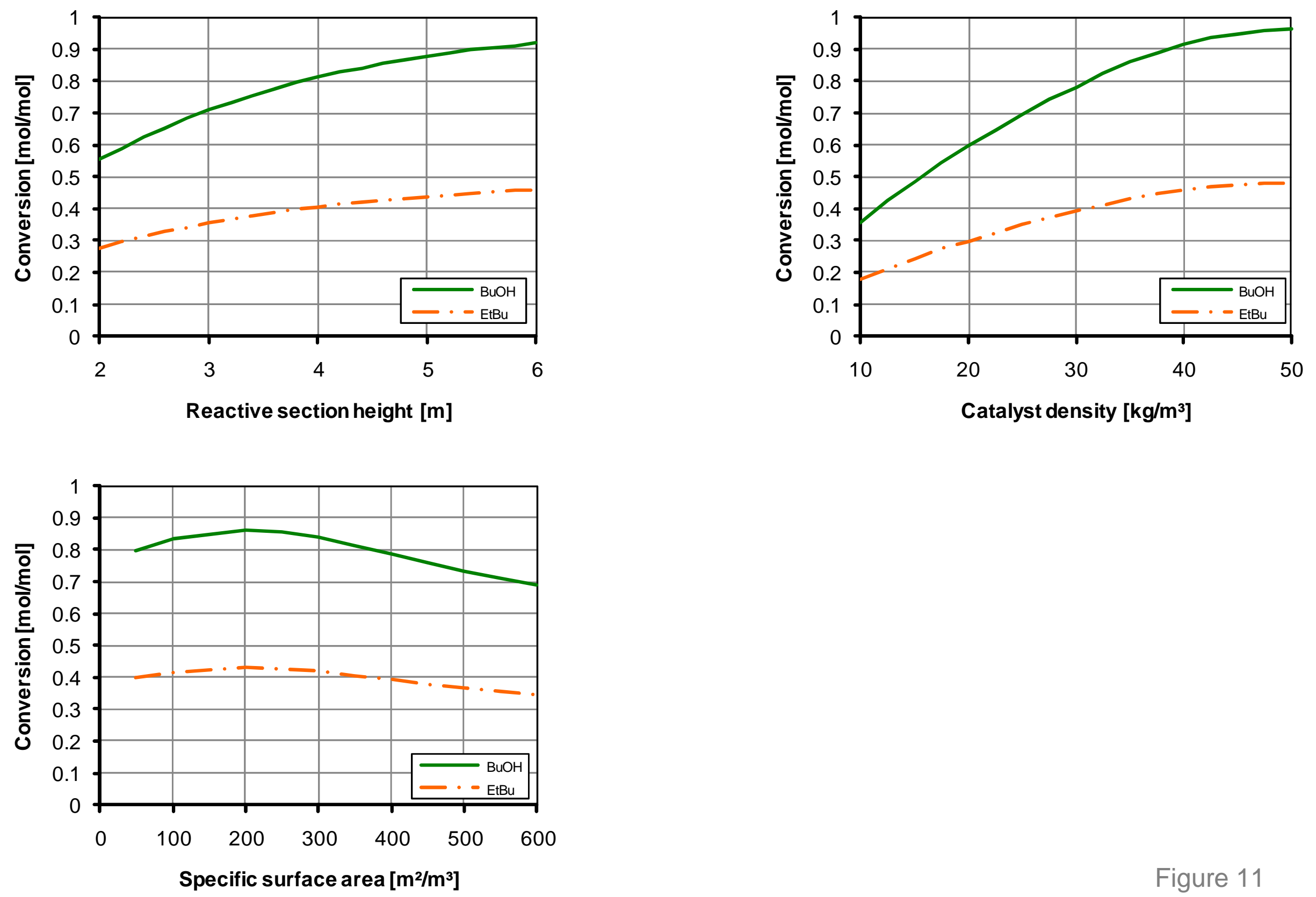